Portland State University

PDXScholar

Fall 1998

\title{
The Evolving Role of Semiconductor Consortia in the United States and Japan
}

\author{
Rose Marie Ham \\ University of California - Berkeley \\ Greg Linden \\ University of California - Berkeley \\ Melissa M. Appleyard \\ Portland State University, appleyar@pdx.edu
}

Follow this and additional works at: https://pdxscholar.library.pdx.edu/busadmin_fac

Part of the Business Administration, Management, and Operations Commons

Let us know how access to this document benefits you.

\section{Citation Details}

Ham, R., Linden, G., \& Appleyard, M. M. (1998). The Evolving Role of Semiconductor Consortia in the United States and Japan. California Management Review, 41(1), 137-163.

This Article is brought to you for free and open access. It has been accepted for inclusion in Business Faculty Publications and Presentations by an authorized administrator of PDXScholar. Please contact us if we can make this document more accessible: pdxscholar@pdx.edu. 


\title{
The Evolving Role of Semiconductor Consortia in the United States and Japan
}

\author{
Rose Marie Ham \\ Greg Linden \\ Melissa M. Appleyard
}

ince the late 1970s, governments throughout the industrialized economies have proclaimed the benefits of research consortia. In the United States, for example, the 1984 National Cooperative Research Act (NCRA) relaxed U.S. antitrust laws to encourage the formation of research consortia by firms in the same industry; by the end of 1995, over 575 consortia had been registered under the NCRA in a variety of industries, including automobiles, aerospace, and telecommunications. ${ }^{1}$ Governments in the United States, Japan, and Western Europe also launched a myriad of cooperative R\&D programs during the 1980 s, often providing subsidies to large-scale consortia among firms in "strategic" high-technology industries. ${ }^{2}$ These policy initiatives were fueled by concerns over the competitiveness of domestic firms in high-technology sectors combined with the perceived advantages of research consortia ${ }^{3}$ - by banding together in cooperative R\&D activities, firms could share the risks and costs associated with technology generation and thereby compete more effectively in international markets.

The semiconductor industry has pioneered in these large-scale R\&D consortia. ${ }^{4}$ In part, the leading role of this industry in programs establishing R\&D

\footnotetext{
We gratefully acknowledge William J. Spencer (SEMATECH), Frank Robertson (1300I), Hiroyoshi Komiya (Selete), Taro Okabe (SIRI)), and other representatives from the semiconductor industry for sharing their time and insights with us. We also thank David Mowery for his useful comments and suggestions on earlier versions of this article, Jeff Macher for his assistance in obtaining industry data, and George Lee of the SEMI trade association for enabling us to attend SEMI conferences on the $300 \mathrm{~mm}$ wafer transition. Support for this research was provided by the Californio Management Review, the Darden Foundation (Appleyard), the Alfred P. Sloan Foundation (Appleyard and Ham), and the Air Force Office of Scientific Research (Ham). The authors assume full responsibility for any remaining errors or omissions.
} 
consortia reflects its high political saliency in the United States, Japan, and Western Europe. Recognizing that semiconductors are critical inputs to a broad base of electronics, telecommunications, and military-related technologies, governments have promoted a strong domestic semiconductor industry and a viable base of domestic firms to supply the tools and materials used in semiconductor manufacturing. At the same time, these national objectives have had to confront the global realities of the semiconductor industry: semiconductor manufacturers have long operated production facilities throughout the industrialized world, and manufacturers and supplier firms are enmeshed in a complex web of alliances within and across national borders. ${ }^{5}$

Two of the most influential high-technology R\&D consortia of the past 30 years were established with the aid of public funds to support semiconductorrelated R\&D. During the mid-1970s, the Japanese government, concerned about the survival of its computer industry in the face of market liberalization, established the Very Large Scale Integration (VLSI) Project to improve domestic capabilities for manufacturing semiconductor devices used in mainframe computers. ${ }^{6}$ The VLSI Project, along with a parallel set of semiconductor projects sponsored by Japan's state-owned telecommunications firm (NTT), was later credited with enabling Japanese semiconductor firms to "catch up" with U.S. firms in this industry. ${ }^{7}$ By the mid-1980s, Japanese firms had surpassed U.S. device makers in the worldwide markets for semiconductor memory devices. This rise to dominance of Japanese semiconductor manufacturers ignited debate in the United States over the health of the U.S. semiconductor industry and the potential dependence by U.S. defense agencies on Japanese firms for semiconductors used in military systems. In response, the U.S. government and leading U.S. semiconductor manufacturers launched the U.S. Semiconductor Manufacturing Technology (SEMATECH) consortium in 1987 in order to improve the manufacturing capabilities of domestic semiconductor firms.

This article examines a new chapter in the history of large-scale semiconductor consortia in the United States and Japan. By focusing on two recently established consortia-the International 300mm Initiative (I300I) in the United States and Semiconductor Leading Edge Technologies, Inc. (Selete) in Japanwe examine the changing role of governments and private firms in directing technology development in the semiconductor industry. ${ }^{8}$ Unlike the VLSI Project and SEMATECH consortia, both I300I and Selete have been financed solely by member companies and are working with a global base of supplier firms, apparently heralding a sea change in relations between the semiconductor industry and national governments. These consortia also include leading semiconductor manufacturers from around the world, which reflects the need to spread costs across a larger number of firms and highlights the new prominence of Taiwanese and South Korean firms in semiconductor manufacturing.

This article examines the factors that gave rise to these new semiconductor RED consortia in the United States and in Japan-namely, the costly conversion to larger silicon wafers that alters many of the industry's manufacturing 
technologies. ${ }^{9}$ It then discusses the origins and structures of these consortia and examines the unprecedented level of cooperation among leading semiconductor manufacturers that is taking place. Although their efforts are still underway, the consortia have already confronted the difficulties associated with large-scale collaborative R\&D endeavors that involve uncertain technologies and volatile market forces. The semiconductor industry may be unique in sustaining this level of industry-wide cooperation, but the lessons from the current semiconductor consortia apply to managers involved in large-scale collaborative ventures in other technology-intensive industries.

With respect to the role of government, the two consortia highlight divergent trends. I300I illustrates the political challenges associated with transforming a domestically oriented, federally subsidized consortium into an institution supported solely by dues from domestic and foreign firms. By contrast, Selete was formed in conjunction with a new wave of government-funded semiconductor R\&D projects in Japan, and the private consortium shares important ties with these parallel, public-sector initiatives. Despite predictions that the actions of national governments will be curtailed in an era of global, high-technology firms, ${ }^{10}$ home-country governments continue to exercise considerable influence on these private initiatives, as they do in other high-technology sectors. Nonetheless, the ultimate effects of government initiatives may be more easily offset or even derailed by the actions of global firms.

\section{The Challenge of Converting to $300 \mathrm{~mm}$ Wafers}

The semiconductor industry has a unique combination of capital- and research-intensity that, combined with short product life cycles and a rapid pace of technological change in the industry, magnifies investment risks for firms. ${ }^{11}$ Individual semiconductor investments are quite large, with new factories (known as "fabs") costing at least $\$ 1$ billion. At the same time, the pace of semiconductor technology development has increased, shortening the useful life of capital investments. According to an industry executive: "In the mid-80s, a fab cost about $\$ 100$ million and had an expected life span of nearly 10 years. Now we have $\$ 1$ billion fabs with a life span of only five years." ${ }^{12}$

Semiconductor manufacturing processes also are among the most complex in any industry. ${ }^{13}$ The fabrication of an integrated circuit (also known as a "chip" or "device") requires more than a hundred steps (such as patterning, coating, baking, etching) across a range of specialized tool sets. An average fabrication facility in 1997 utilized about 40 different types of equipment, with individual tools ranging in price from $\$ 100,000$ to $\$ 7$ million. ${ }^{14}$ The individual manufacturing steps are often mastered at an experimental rather than a scientific level and are difficult to replicate on different tools or in different facilities. Such complexity has historically required manufacturers to work closely with equipment suppliers to improve the performance of each tool. 
In response to the soaring capital costs and risks of semiconductor manufacturing, producers throughout the world have developed an array of strategies, among the most important of which is interfirm collaboration in RED and production investments. A new challenge has given an additional impetus to these collaborative trends. Driven by the need to produce increasing numbers of semiconductor chips at lower prices, semiconductor manufacturers and their equipment suppliers are now preparing to upgrade their manufacturing methods and production tools to accommodate $300 \mathrm{~mm}$ silicon wafers instead of the current $200 \mathrm{~mm}$ wafer standard. ${ }^{15}$ Larger wafers also will more easily accommodate complex chip designs, such as next-generation microprocessors and systems-on-achip, early versions of which may be too large to manufacture economically on smaller silicon wafers. ${ }^{16}$

In contrast to previous wafer transitions, the shift from $200 \mathrm{~mm}$ to $300 \mathrm{~mm}$ wafers will not be orchestrated by any single firm in the industry, for two reasons. First, experts estimate the costs and technical challenges associated with the shift to $300 \mathrm{~mm}$ wafers to be an order of magnitude greater than those of previous wafer transitions. ${ }^{17}$ The shift to $300 \mathrm{~mm}$ wafers necessitates a more radical overhaul of equipment tool sets than was true of previous wafer transitions, and also requires a fundamental alteration in the overall design of fabrication facilities. For example, $300 \mathrm{~mm}$ wafers are so large and fragile that they necessitate a higher level of automation than is used in $200 \mathrm{~mm}$ fabs, requiring the development of new interfaces, carriers, and software. The total development costs of $300 \mathrm{~mm}$ tools are likely to exceed $\$ 10$ billion, far higher than the roughly $\$ 1$ billion cost of developing $200 \mathrm{~mm}$ tools in the early $1980 \mathrm{~s}^{18}$

A second and related reason for the lack of single-firm leadership in the $300 \mathrm{~mm}$ wafer transition is the experiences of Intel and IBM in leading previous wafer transitions. In each of these transitions, the "lead company" (Intel for the $100-150 \mathrm{~mm}$ transition; IBM led the $150-200 \mathrm{~mm}$ transition) purchased or produced test wafers, subsidized equipment development, and guaranteed procurement contracts for production-worthy tools. ${ }^{19}$ Representatives of Intel and IBM report that the costs of individually leading these transitions (especially the need to subsidize the development of new equipment whether or not it was eventually purchased) outweighed the benefits of having first access to the new capabilities. ${ }^{20}$ Intel took two years longer than expected to reach full volume production in its first $150 \mathrm{~mm}$ fab, and IBM faced similar problems improving the reliability of its new $200 \mathrm{~mm}$ tools. ${ }^{21}$ Such production delays and unanticipated tool development costs undermined the profitability of being first to manufacture chips on the new wafers.

Since the costs of "going it alone" with the current wafer transition are so high and no single firm can fully appropriate the returns from that investment, a strategy of sharing some of the costs and risks across a large number of firms has emerged. For the first time in the history of the industry, leading international device makers developed a uniform set of standards in advance of a major wafer transition. ${ }^{22}$ In setting these standards, device makers hoped to speed tool devel- 
opment and to reduce the costs of obtaining a compatible $300 \mathrm{~mm}$ tool set for next-generation fabs. For example, the previous, piecemeal transitions led by single firms produced a range of incompatible equipment, forcing chip makers to develop custom mechanical interfaces or limit their choice of suppliers. Ten different carrier systems were used for $200 \mathrm{~mm}$ wafers, whereas device makers in the two $300 \mathrm{~mm}$ consortia have agreed to accept only two carrier systems for $300 \mathrm{~mm}$ wafers, both of which must be accommodated by suppliers. Finally, the history of successful collaboration among leading U.S. device makers in managing joint projects with supplier firms (e.g., under the auspices of SEMATECH) may have reduced the transaction costs associated with launching a cooperative wafer conversion initiative.

\section{Consortium-Led Technological Change}

By 1996, two consortia had been formed to lead the conversion of the industry's capital equipment. The U.S.-based International $300 \mathrm{~mm}$ Initiative (I300I) consortium, established in late 1995, comprises 13 leading device makers, including firms from the United States (Intel, Texas Instruments, Motorola, IBM, AMD, and Lucent Technologies), Europe (STMicroelectronics, ${ }^{23}$ Philips, and Siemens), South Korea (Samsung Electronics, Hyundai Electronics, and LG Semicon), and Taiwan (Taiwan Semiconductor Manufacturing Corporation, TSMC) ${ }^{24}$ A parallel effort was established in Japan, when ten leading Japanese semiconductor firms (NEC, Hitachi, Toshiba, Mitsubishi, Fujitsu, Matsushita, Sanyo, Oki, Sharp, and Sony) established Semiconductor Leading Edge Technologies, Inc. (Selete) in early $1996 .{ }^{25}$ Together, these consortia include more than 20 leading semiconductor manufacturers that account for most of the world's chip production (Table 1).

As this membership roster demonstrates, the device makers-not equipment suppliers-are leading the wafer conversion effort. The ability of leading manufacturers from around the world to establish joint technical standards and set goals for a broad base of suppliers is relatively rare, even though buyers are typically more eager for standards than suppliers, who prefer higher levels of product differentiation ${ }^{26}$ In this case, the ability of the device firms to dictate the conversion schedule to their suppliers reflects not only the collective market power of these customers, but also the technical dependence of suppliers on the device makers. ${ }^{27}$ Although other industries, such as autos, also exhibit a close working relationship between equipment suppliers and their customers, the complexity of semiconductor process technology has historically required suppliers to look to device makers for technical guidance. ${ }^{28}$ Device makers often provide both funding and engineering resources to their suppliers for specific projects. One U.S. device maker, for example, estimated that it financed approximately 20 percent of the $\$ 15$ million cost and nearly 40 percent of the $14,000+$ engineering hours associated with a recent unsuccessful equipment modification 
TABLE I. Founding Members of I300I and Selete (by nationality and 1995 IC sales)

\begin{tabular}{|c|c|c|}
\hline 13001 & $\begin{array}{c}1995 \text { IC } \\
\text { sales }^{2}(\$ b)\end{array}$ & $\begin{array}{l}1995 \text { Rank in } \\
\text { world IC sales }\end{array}$ \\
\hline \multicolumn{3}{|l|}{ U.S. Members } \\
\hline Intel & $\$ 13.6$ & 1 \\
\hline Texas Instruments & $\$ 7.8$ & 6 \\
\hline Motorola & $\$ 7.2$ & 7 \\
\hline IBM & $\$ 5.7$ & 8 \\
\hline AMD & $\$ 2.4$ & 17 \\
\hline Lucent & $\$ 1.7$ & 24 \\
\hline $\begin{array}{l}\text { Combined } 1995 \text { IC sales } \\
\text { (\% of all U.S. firms' IC sales) }\end{array}$ & $\begin{array}{l}\$ 38.4 \\
(63 \%)\end{array}$ & \\
\hline \multicolumn{3}{|l|}{ European Members } \\
\hline STMicroelectronics (Italy/France) & $\$ 3.0$ & 13 \\
\hline Philips (Netherlands) & $\$ 2.9$ & 14 \\
\hline Siemens (Germany) & $\$ 2.4$ & 18 \\
\hline $\begin{array}{l}\text { Combined } 1995 \mathrm{IC} \text { sales } \\
\text { (\% of all European firms' IC sales) }\end{array}$ & $\begin{array}{l}\$ 8.3 \\
(78 \%)\end{array}$ & \\
\hline \multicolumn{3}{|l|}{ Korean and Taiwanese Members } \\
\hline Samsung Electronics (S. Korea) & $\$ 8.2$ & 5 \\
\hline Hyundai Electronics (S. Korea) & $\$ 4.4$ & 10 \\
\hline LG Semicon, Inc (S. Korea) & $\$ 3.6$ & 12 \\
\hline TSMC (Taiwan) & $\$ 1.4$ & 25 \\
\hline $\begin{array}{l}\text { Combined } 1995 \text { IC sales } \\
\text { (\% of all Korean \& Taiwanese firms' IC sales) }\end{array}$ & $\begin{array}{l}\$ 17.6 \\
(83 \%)\end{array}$ & \\
\hline I300I Members' total I995 IC sales & $\$ 64.3$ & \\
\hline
\end{tabular}

project. ${ }^{29}$ As this example suggests, such buyer-supplier collaboration contains risks for both parties. ${ }^{30}$

\section{Origin and Structure of I300I and Selete}

The structure and RED operations of both I300I and Selete have been influenced by previous successful and unsuccessful large-scale R\&D consortia in the United States and Japan. In particular, the new consortia incorporate key features of the VLSI Project and SEMATECH consortia: even though member firms in both I300I and Selete are "horizontal" competitors in the semiconductor market, these consortia focus on "vertical" projects aimed at ensuring the reliability and compatibility of production tools. Also, like earlier semiconductor consortia, I300I and Selete need to define a research agenda and design a structure 
TABLE I. Founding Members of $\mathrm{I} 300 \mathrm{I}$ and Selete (continued)

\begin{tabular}{lcc|}
\hline Selete & $\begin{array}{c}\text { I995 IC } \\
\text { sales }^{\mathbf{a}} \mathbf{( \$ b )}\end{array}$ & $\begin{array}{c}\text { I995 Rank in } \\
\text { world IC sales }^{\mathbf{b}}\end{array}$ \\
\hline Japanese Members & $\$ 11.0$ & 2 \\
\hline NEC & $\$ 8.6$ & 3 \\
\hline Hitachi & $\$ 8.6$ & 4 \\
\hline Toshiba & $\$ 4.4$ & 9 \\
\hline Mitsubishi & $\$ 4.0$ & 11 \\
\hline Fujitsu & $\$ 2.6$ & 16 \\
\hline Matsushita & $\$ 2.3$ & 20 \\
\hline Sanyo & $\$ 2.0$ & 21 \\
\hline Oki & $\$ 2.0$ & 22 \\
\hline Sharp & $\$ 1.9$ & 23 \\
\hline Sony & $\$ 47.4$ & \\
\hline $\begin{array}{l}\text { Combined } 1995 \text { IC sales } \\
\text { (\% of all Japanese firms' IC sales) }\end{array}$ & $(91 \%)$ & \\
\hline
\end{tabular}

Notes:

a. Source: ICE, Status: A Report on the Integrated Circuit Industry (Scottsdale, AZ: Integrated Circuit Engineering, Inc., 1997), based on sales of merchant firms.

b. All but two of the top 25-ranked IC manufacturers joined either 1300 I or Selete. Micron Technology, a U.S. firm ranked I5th, was a founding member of SEMATECH but withdrew from the consortium in 1992. National Semiconductor, a U.S. firm ranked 19th, is a member of both SEMATECH and its newly-formed international subsidiary, International SEMATECH. but was not a founding member of 13001 .

that facilitates, rather than impedes, effective cooperation both among member firms and between members and participating suppliers. Despite some similarity in their objectives, I300I and Selete have devised divergent solutions to these challenges, which are central to any large-scale cooperative R\&D program.

\section{The International $300 \mathrm{~mm}$ Initiative}

The International 300mm Initiative was formally established in late 1995 as the first international subsidiary of the U.S. Semiconductor Manufacturing Technology (SEMATECH) consortium. I300I started as an 18-month, \$26 million project (roughly $\$ 2$ million per member firm). According to SEMATECH representatives, early plans for I300I included an annual budget as high as $\$ 100 \mathrm{mil}-$ lion, but prospective participants selected a less costly project. I300I's activities have been extended into 1999, and the consortium now receives roughly $\$ 24$ million per year in dues paid by member firms. I300I is housed in SEMATECH's Austin, Texas, facility and rents clean-room space from SEMATECH. ${ }^{31}$

The design of I300I builds directly on the experience of SEMATECH. First, I300I adopted SEMATECH's system of employing assignees from member firms to facilitate the transfer of information back to their parent organizations. 
Approximately 90 percent of 1300I's technical positions are staffed by memberfirm assignees. ${ }^{32}$ Second, I300I employs SEMATECH's cost-of-ownership (COO) model to establish the basic guidelines and information on equipment cost and performance. ${ }^{33}$ The design and management of I300I's activities also drew on the accumulated experience of SEMATECH managers, which may have enabled I300I to begin its operations more quickly and easily than would have otherwise been possible.

A third feature of $\mathrm{I} 300 \mathrm{I}$ reflects the lessons of SEMATECH in defining a research agenda that facilitates cooperation among competing firms. In the second year of its operation, SEMATECH redirected its research agenda away from collaborative projects among device makers aimed at improving their manufacturing process technologies toward projects between these semiconductor manufacturers and their U.S. suppliers of semiconductor equipment and materials. The main reason for the "vertical" shift was the reluctance of U.S. device makers to share process technologies with one another that were critical to the market success of these competing firms ${ }^{34}$ Although this redirection in SEMATECH's activities simplified collaboration among device makers, it created considerable concern among equipment suppliers over the sharing or leakage of proprietary information. In response to these concerns, most of SEMATECH's equipment projects now take place at the facilities of individual supplier firms instead of the consortium's common facility, and suppliers generally own any project-related intellectual property. Consistent with this experience, I300I has adopted a decentralized approach to working with suppliers and, like SEMATECH, evaluates most equipment at suppliers' sites, using engineers from both I300I and the participating supplier firm. ${ }^{35}$ This arrangement provides suppliers with immediate feedback on the performance of their tools and reduces the danger that proprietary information will "leak" among competing suppliers.

Unlike SEMATECH, however, I300I does not directly fund equipment development. Although SEMATECH continues to sponsor joint development and equipment improvement projects with suppliers, I300I simply evaluates tools for basic test parameters, leaving the development and subsequent improvement of those tools to suppliers. ${ }^{36}$ Given its commitment to tool evaluation rather than development, I300I does not expect to own any intellectual property based on its work with suppliers. In contrast, SEMATECH obtained 89 patents between 1989 and 1996 based on research conducted or funded by the consortium, although the consortium now places less emphasis on owning intellectual property from projects with suppliers. ${ }^{37}$

\section{Semiconductor Leading Edge Technologies, Inc.}

The Japan-based Selete consortium is a more ambitious collaborative RED program aimed at both the evaluation and development of $300 \mathrm{~mm}$ tools. The proposal for Selete was made in 1995 by the Semiconductor Industry Research Institute Japan (SIRIJ), an industry group formed a year earlier by the ten largest Japanese chip producers as part of a broader effort to "reactivate 
Japan's semiconductor industry." ${ }^{38}$ Together, the members of this industry organization (NEC, Hitachi, Toshiba, Mitsubishi, Fujitsu, Matsushita, Sanyo, Oki, Sharp, and Sony) accounted for 91 percent of all Japanese firms' IC sales in $1995 .^{39}$

Following some discussion of joining the U.S.-based 300mm efforts, the ten leading Japanese device makers in SIRIJ chose to establish a separate consortium in $1996 .^{40}$ The Japanese participants of Selete committed approximately $\$ 280$ million for a five-year 300mm program, an annual budget more than twice that of I300I (and nearly three times as large on a per-member basis). This larger R\&D budget supports a broader program of collaboration and defrays a higher share of the costs associated with $300 \mathrm{~mm}$ equipment evaluation and development, incurred primarily by suppliers in I300I. For example, unlike I300I, Selete pays the full cost of the expensive test wafers used in the equipment evaluations. ${ }^{41}$ Selete also established a dedicated clean-room facility in Hitachi's Production Engineering Research Laboratory and purchased test equipment for this facility. ${ }^{42}$ I300I's rented facility does not house an entire production line and its test equipment is either under evaluation or donated by suppliers.

Yet another notable difference between Selete and I300I is Selete's greater centralization. In contrast to I300I, equipment is typically evaluated in Selete's central laboratory rather than in suppliers' facilities. Evaluations are primarily performed by Selete engineers on assignment from member firms. Tool performance is communicated to the supplier in a weekly report that may include suggestions for improvements in the tool. Originally, all of the tools were evaluated at the central Selete facility. As the early experience of SEMATECH suggests, however, the risk of technology leakage among supplier firms may increase when tool-related projects are conducted in a common facility. ${ }^{43}$ Recognizing the need to ensure confidentiality to suppliers, Selete established temporary barriers between similar tools under evaluation at Selete. Selete also modified its original structure and is evaluating some equipment at suppliers' facilities. $^{44}$

In addition to evaluating equipment, Selete also develops and modifies $300 \mathrm{~mm}$ tools, in contrast to the I300I consortium where suppliers are solely responsible for improving and developing their tools. From its inception, Selete has been committed to generating jointly owned intellectual property based on improvements suggested by Selete engineers to the tools under evaluation. ${ }^{45}$ As of mid-April 1998, Selete had finished ten evaluations and was in the process of conducting about 30 more. By the end of fiscal year 1998, the group expects to apply for 10 to 20 patents, most of which would be jointly owned by Selete and individual equipment suppliers. ${ }^{46}$

\section{Discussion}

The key differences between I300I and Selete are summarized in Table 2. Selete evaluates tools for a longer time period (up to nine months, versus a 6 month maximum at I300I) and in a central facility that includes all the elements 
TABLE 2. Key features of 13001 and Selete

\begin{tabular}{|c|c|c|}
\hline & $\begin{array}{l}\text { International } \\
300 \mathrm{~mm} \text { Initiative } \\
(13001)\end{array}$ & $\begin{array}{l}\text { Semiconductor Leading } \\
\text { Edge Technologies, Inc. } \\
\text { (Selete) }\end{array}$ \\
\hline Founding Members & $\begin{array}{l}6 \text { U.S. firms } \\
3 \text { European firms } \\
3 \text { Korean firms } \\
1 \text { Taiwanese firm }\end{array}$ & 10 Japanese firms ${ }^{b}$ \\
\hline Location & $\begin{array}{l}\text { Austin, Tx, USA } \\
\text { (SEMATECH clean room) }\end{array}$ & $\begin{array}{l}\text { Yokohama City, Japan } \\
\text { (Hitachi Laboratory) }\end{array}$ \\
\hline Date Established & November 1995 & February 1996 \\
\hline Budget (annual average) & $\$ 24$ million & $\$ 56$ million ( $¥ 7$ billion) \\
\hline Staff size (approx.) & 68 & 150 \\
\hline Primary evaluation site & $\begin{array}{l}\text { suppliers' facilities } \\
\text { and } 1300 \mid \text { clean room }\end{array}$ & central Selete clean room \\
\hline Type of tests & unit processes & short loops \\
\hline $\begin{array}{l}\text { Guidance in } \\
\text { technology development }\end{array}$ & Indirect & Direct \\
\hline $\begin{array}{l}\text { Generation of } \\
\text { Intellectual Property? }\end{array}$ & $\begin{array}{l}\text { No } \\
\text { (supplier-owned) }\end{array}$ & $\begin{array}{l}\text { Yes } \\
\text { (both Selete-owned and Selete- } \\
\text { supplier-owned anticipated) }\end{array}$ \\
\hline
\end{tabular}

Notes:

a. Samsung Electronics Co. and LG Semicon, Inc. terminated their membership in I300I at the end of I997 ("Samsung Stays in Japan's $300 \mathrm{~mm}$ Group After Leaving SEMATECH's," Electronic Buyers' News Daily Digest, February 4, 1998).

b. Samsung agreed to participate in Selete in 1997, but is not a stockholder of the consortium.

of a full fabrication line. Selete also does more comprehensive electrical testing of device substructures ("short loops") based on a fully specified process "recipe," which helps assess the performance of a tool when it is integrated with other production steps. By contrast, I300I is limited to "demonstrations" of tool performance ("unit processes"), many of which are conducted at supplier sites, and its clean-room facility is primarily used for technical support and wafer inspection. These and other differences have contributed to difficulties over sharing of test results between the two consortia. ${ }^{47}$

The two industry consortia have also established very different vertical relationships with supplier firms. Selete is more heavily involved in the development of production equipment, and its participating device makers have agreed to jointly fund a larger share of the development costs associated with the $300 \mathrm{~mm}$ wafer transition. But in contrast to the VLSI Project and SEMATECH consortia of previous decades, these privately funded initiatives are unencumbered by any explicit government directive to improve the health of a domestic base of suppliers. They are pursuing a more "open" policy of evaluating tools from suppliers worldwide. For example, a leading Japanese supplier, Canon, shipped a $300 \mathrm{~mm}$ lithography system for testing at the U.S.-based I300I consor- 
tium in 1997, and other leading suppliers from the United States and Europe are participating in the demonstration activities of both consortia. ${ }^{48}$ By mid-1998, I300I and Selete had evaluated tools from vendors worldwide. Roughly 60 percent of tools evaluated by Selete were from Japanese firms, while slightly more than 50 percent of the tools evaluated by I300I were from U.S. firms. ${ }^{49}$

Despite their differences, I300I and Selete have encountered similar problems during the past 18 months, many of which are attributable to the technical and managerial complexity of the $300 \mathrm{~mm}$ wafer transition. First, not all suppliers have provided their equipment prototypes on schedule. Production-ready $300 \mathrm{~mm}$ tools are still unavailable for some key processing steps, which prevents manufacturers from implementing a complete $300 \mathrm{~mm}$ manufacturing process. For example, Texas Instruments has constructed a new fab, which is sitting empty until a complete set of $300 \mathrm{~mm}$ tools is available. ${ }^{50}$ To address this problem, SEMATECH is weighing a proposal to begin a program in 1999 (led by I300I) to develop tools in the lagging $300 \mathrm{~mm}$ equipment areas. A related issue is whether suppliers will adhere to the standards. I300I members have repeatedly announced that they will demand tools from suppliers that meet the standards set by the consortia, but it is far too soon to know if this will occur in practice. Some companies may continue to demand customized, non-compliant tool sets from equipment suppliers in order to optimize the performance of specific steps for their product lines. ${ }^{51}$

Two other unexpected factors have delayed the $300 \mathrm{~mm}$ conversion efforts. First, faster-than-expected reductions in the line widths of circuit patterns have permitted more chips to fit onto each $200 \mathrm{~mm}$ wafer, extending the productive life of $200 \mathrm{~mm}$ fabs and equipment. Suppliers have also realized that some productivity enhancements, such as mini-environments, which were expected to enter the mainstream only with the $300 \mathrm{~mm}$ generation, can be deployed in $200 \mathrm{~mm}$ fabs. As a result, the early introduction of next-generation $300 \mathrm{~mm}$ tools is now less critical than was previously thought. ${ }^{52}$ Second, the industry downturn that began in 1997 has made manufacturers reluctant to invest in tools for new facilities when their existing fabs are underutilized. The Asian financial and economic crisis exacerbated the effects of the industry downturn on equipment firms by further constraining the capital expenditures of Japanese, Korean, and (more recently) Taiwanese companies.

This combination of technical and economic factors has delayed the transition to $300 \mathrm{~mm}$ wafers. As recently as November 1997, chip makers were predicting that seven $300 \mathrm{~mm}$ pilot lines would be operational in 1998 and that the first high-volume fabs would appear in 2000. As of 1998, however, no 300mm pilot lines are running and high-volume production is not expected until 2002. ${ }^{53}$

For chip makers, the industry downturn and delays in the current wafer transition have highlighted the benefits of collaboration. The risk-sharing arrangement has functioned as planned, with no single firm suffering disproportionate losses. Nevertheless, the downturn has different near-term implications for Selete and I300I. The device manufacturers participating in I300I have 
largely avoided significant expenditures for the joint development of a new generation of capital equipment whose adoption now seems likely to be delayed. Selete members, on the other hand, have incurred more significant costs. Although some interviewees in 1997 had predicted that Selete's centralized, "hands-on" design would permit Japanese semiconductor firms to launch $300 \mathrm{~mm}$ fabs before their U.S. counterparts, Selete members now are saddled with the considerable expense of operating a full $300 \mathrm{~mm}$ clean room in the face of a lack of demand for this technology.

The consequences of the industry downturn on the $300 \mathrm{~mm}$ transition have been more severe for supplier firms. Ironically, equipment firms who made the greatest effort to comply with the original timetable, having spent \$25 million or more to develop each tool, are worse off than those who failed to respect the manufacturers' schedules. These early developers are now unlikely to find significant sales until 2002 or beyond. ${ }^{54}$ In light of continued uncertainty over the timing for an industry upturn, many suppliers have scaled back their $300 \mathrm{~mm}$ plans. The chip makers in I300I, which has shifted virtually all of these risks to suppliers, have responded by calling a series of summit meetings with suppliers to reduce some of the uncertainty they face in their $300 \mathrm{~mm}$ tool development efforts.

This sudden change in the market outlook for $300 \mathrm{~mm}$ technologies illustrates an insufficiently appreciated risk of industry-wide collaboration in environments characterized by fundamental uncertainty, which accurately describes most high-technology industries. The formulation of an industry-wide "vision" or technology "roadmap" may increase, rather than reduce, the risks that unforeseen developments will render the best-laid plans irrelevant. ${ }^{55}$ Timing is difficult in any rapidly changing environment. But the tendency of such industry-wide collaboration to concentrate technological or economic bets may increase the collective exposure of firms to unexpected developments.

\section{Global Firms, National Governments}

The efforts of I300I and Selete are still underway, and their long-range outcomes and effects cannot be forecast with confidence. This uncertainty notwithstanding, the formation and operation of these ventures indicates an unprecedented level of cooperation within and across national borders in preparation for the conversion of the semiconductor industry's capital equipment to new $300 \mathrm{~mm}$ wafers. The U.S.-based I300I program represents the first time that leading semiconductor firms from seven countries have agreed to conduct joint projects on their manufacturing technologies under one organizational umbrella, and these firms are coordinating some of their efforts with the Japanbased Selete consortium. Moreover, both I300I and Selete are evaluating tools from a global base of equipment and materials suppliers. Although device makers have long been engaged in a complex web of bilateral alliances and have purchased tools from specialized suppliers from around the world, this relatively 
high level of international cooperation among such a broad base of competing manufacturers is without parallel in the history of this and other capital-intensive, politically-charged industries (e.g., automobiles or aerospace).

Do these private initiatives support the view that the role of national governments is greatly curtailed in an era of international, high-technology firms? ${ }^{56}$ Not necessarily. On the one hand, I300I suggests that the role of government in these industry-wide efforts is diminishing —with the end of federal funding, this offshoot of the SEMATECH consortium was able to include non-U.S. firms as full members and as participating suppliers. Selete, however, provides weaker support for this view. The Japanese consortium coincides with a new wave of government-funded semiconductor R\&D initiatives in Japan. As discussed below, some of these publicly funded projects were designed to complement those conducted by the private consortium, and several are physically located at Selete's clean-room facility.

\section{Cutting Public Ties: The International Expansion of SEMATECH}

One of the most significant changes in the historic ties between semiconductor research consortia and national governments is illustrated by the international expansion of SEMATECH and the formation of I300I. ${ }^{57}$ From 1987-1996, SEMATECH received over $\$ 850$ million in dues from its members, leading U.S. semiconductor manufacturers, and roughly $\$ 850$ million in matching funds from the U.S. Defense Advanced Research Projects Agency. ${ }^{58}$ Although the industry-government partnership was planned to last from 1987-1992, federal contributions continued for an additional four years. By the mid-1990s, however, improvements in the health of the U.S. semiconductor industry and its domestic supplier base coincided with a shift in Congressional attitudes to a more skeptical view of programs aimed at assisting industrial sectors such as semiconductors. ${ }^{59}$ Federal funding of SEMATECH ceased in 1996.

With federal funds drawing to an end, SEMATECH faced a choice between scaling back its research agenda or attracting additional dues-paying members. In the end, it did both. In 1995, SEMATECH began reducing its operating budget to prepare for the end of federal funding and initiated plans for including non-U.S. firms in a set of international projects. In this context, one of I300I's most significant accomplishments to date may be its role in paving the way for an expansion of SEMATECH. In 1998, the remaining members of I300I joined a new, more ambitious "International SEMATECH" (see Table 3), another subsidiary of SEMATECH. Assignees of firms from seven countries will work on a set of joint International SEMATECH projects, including the continued $300 \mathrm{~mm}$ activities of I300I, a larger project on photolithography (one of the most critical technologies used in semiconductor manufacturing), and two other projects on manufacturing methods and environmental, safety, and health standards. ${ }^{60}$ In 1999, I300I (now a division of International SEMATECH) expects to phase out its tool evaluation activities and take on the more difficult task of selecting tools for joint development or improvement projects. ${ }^{61}$ 
TABLE 3. Members of SEMATECH, International SEMATECH, and I300I

\begin{tabular}{|c|c|c|c|}
\hline $\begin{array}{l}\text { Original } \\
\text { SEMATECH }\end{array}$ & $\begin{array}{l}\text { International } \\
\text { SEMATECH }\end{array}$ & $\begin{array}{l}\text { Original } \\
13001\end{array}$ & $\begin{array}{l}\text { New } \\
\text { I300| }\end{array}$ \\
\hline AMD & AMD & AMD & AMD \\
\hline Digital Semiconductor & Digital Semiconductor & & Digital Semiconductor ${ }^{d}$ \\
\hline Hewlett Packard & Hewlett Packard & & Hewlett Packard \\
\hline $\mathrm{IBM}$ & IBM & $\mathrm{IBM}$ & IBM \\
\hline Intel & Intel & Intel & Intel \\
\hline Lucent (AT\&T) & Lucent & Lucent & Lucent \\
\hline Motorola & Motorola & Motorola & Motorola \\
\hline National Semicon. & National Semicon. & & National Semicon. \\
\hline Rockwell & Rockwell & & Rockwell \\
\hline Texas Instruments & Texas Instruments & Texas Instruments & Texas Instruments \\
\hline \multicolumn{4}{|l|}{ Harris Semiconductor } \\
\hline \multicolumn{4}{|l|}{ LSI Logic ${ }^{b}$} \\
\hline \multicolumn{4}{|l|}{ Micron Technologyb } \\
\hline & Hyundai (S Korea) & Hyundai (S. Korea) & Hyundai (S. Korea) \\
\hline & $\begin{array}{l}\text { Philips Semicon. } \\
\text { (Europe) }\end{array}$ & $\begin{array}{l}\text { Philips Semicon. } \\
\text { (Europe) }\end{array}$ & $\begin{array}{l}\text { Philips Semicon, } \\
\text { (Europe) }\end{array}$ \\
\hline & Siemens (Europe) & Siemens (Europe) & Siemens (Europe) \\
\hline & $\begin{array}{l}\text { STMicroelectronics } \\
\text { (Europe) }\end{array}$ & $\begin{array}{l}\text { STMicroelectronics } \\
\text { (Europe) }\end{array}$ & $\begin{array}{l}\text { STMicroelectronics } \\
\text { (Europe) }\end{array}$ \\
\hline & TSMC (Taiwan) & TSMC (Taiwan) & TSMC (Taiwan) \\
\hline & & LG Semicon (5. Korea) ${ }^{c}$ & \\
\hline & & Samsung (S. Korea) $)^{c}$ & \\
\hline
\end{tabular}

Notes: a. Withdrew from SEMATECH in 1993

b. Withdrew from SEMATECH in 1992

c. Withdrew from 13001 in 1997

d. Acquired by Intel in May 1998

Sources: SEMATECH: modified from Global $300 \mathrm{~mm}$ Report, June 1998.

This international expansion of SEMATECH created some political concerns among its former supporters in the federal government. Although SEMATECH's government funding had ended, its plans to include European, Taiwanese, and Korean firms in its research programs raised concerns in Washington that the body of manufacturing knowledge created by SEMATECH over the past decade with the aid of federal monies would "spill over" to non-U.S. firms. Executives at SEMATECH adopted several procedures to allay these political concerns. For example, the foreign companies participating in International SEMATECH must obtain written permission from SEMATECH in order to use unpublished technical data generated by SEMATECH members with past federal 
assistance. In addition, foreign members of the consortium were not guaranteed the right to license SEMATECH patents and must obtain written approval for use of these inventions. ${ }^{62}$

Nevertheless, it is noteworthy that SEMATECH's international offshoot includes no Japanese semiconductor firms. Given the fact that SEMATECH's original objectives were to improve the competitiveness of U.S. semiconductor manufacturers relative to their Japanese competitors, Japanese membership in an international subsidiary of SEMATECH may well have been politically infeasible. At a minimum, the inclusion of Japanese device makers in International SEMATECH would have increased the intensity of the political criticism. ${ }^{63}$

\section{Renewed Industry-Government Partnerships in Japan?}

The Japanese-led Selete consortium illustrates a very different relationship between the private consortium and public-sector initiatives. Selete is one of several important Japanese semiconductor projects that have been launched in the past few years. Collectively, these projects represent the largest set of private-public programs aimed at semiconductor technologies since the wellknown VLSI Project of the 1970 s. ${ }^{64}$ Organizational walls divide the private initiatives from public ones within this collection of projects. Nonetheless, the origins and broader research agenda of Selete are enmeshed with important semiconductor projects funded by Japan's Ministry of International Trade and Industry (MITI), even though Selete's $300 \mathrm{~mm}$ program is funded and led entirely by private firms.

In the early stages of Selete's establishment, the ten Japanese device makers (in the SIRIJ industry group) sought government funding for two broad areas of collaborative R\&D-300mm evaluation and development, and five other semiconductor projects aimed at refining and developing more advanced manufacturing technologies. After reviewing the SIRIJ proposal, MITI agreed to fund the latter set of semiconductor projects as part of a new consortium, the Association of Super-advanced Electronics Technologies (ASET). ${ }^{65}$ ASET was launched in early 1996, and received $\$ 100$ million from MITI during the first year of its operation (see Table 4). ${ }^{66}$ Separately, SIRIJ members established a parallel $300 \mathrm{~mm}$ program in the privately funded Selete consortium.

The common origins of Selete and the semiconductor projects of ASET are reflected in the complementary design of the two research endeavors. ${ }^{67}$ During the first two years of its operations, for example, ASET rented clean-room space from Selete. Two of ASET's semiconductor projects (in advanced lithography) were physically located at Selete's central facility and were run by members of Selete. Finally, in 1997, the results of one of ASET's capstone semiconductor projects (in ArF lithography) were transferred to Selete for continued development. ${ }^{68}$

The renewed partnership between Japanese device makers and the Japanese government is not, however, a simple replay of the past. Most notably, 
TABLE 4. An Overview of Major and Recent Semiconductor Consortia in the United States and Japan

\begin{tabular}{|c|c|c|c|}
\hline Consortium & Years & $\begin{array}{l}\text { Average Annual } \\
\text { Budget (current } \$)^{a}\end{array}$ & $\begin{array}{l}\text { Percent } \\
\text { Public Funds }\end{array}$ \\
\hline VLSI Project & $\begin{array}{l}1976-86 \\
\text { (Government funds } \\
\text { ended in 1980) }\end{array}$ & $\begin{array}{l}\$ 70 \text { million (FY 1976-79) } \\
\$ 40 \text { million (FY 1980-86) }\end{array}$ & $\begin{array}{l}1976-79: 40 \% \\
1980-86: 0 \%\end{array}$ \\
\hline SEMATECH & $\begin{array}{l}\text { 1987-present } \\
\text { (Government funds } \\
\text { ended FY 1996) }\end{array}$ & $\begin{array}{l}\$ 200 \text { million }(1988-94) \\
\$ 180 \text { million }(1995-96)^{\mathrm{b}} \\
\$ 160 \text { million }(1997-98)^{\mathrm{c}}\end{array}$ & $\begin{array}{l}1988-94: 50 \% \\
1995-96: 50 \% \\
1997-98: 0 \%\end{array}$ \\
\hline 13001 & 1996-present & $\$ 24$ million & $0 \%$ \\
\hline $\begin{array}{l}\text { International } \\
\text { SEMATECH } \\
\text { (incl. 1300I) }\end{array}$ & 1998-present & $\begin{array}{l}\$ 75 \text { million } \\
\text { (April-December 1998) }\end{array}$ & $0 \%$ \\
\hline Selete & 1996-present & $\$ 56$ million & $0 \%$ \\
\hline ASET & 1996-present & $\begin{array}{l}\$ 70 \text { million (of which } \\
\text { approximately } 80 \% \text { is } \\
\text { semiconductor-related) }\end{array}$ & $\begin{array}{l}100 \% \text { (firms pay } \\
\text { indirect costs only) }\end{array}$ \\
\hline
\end{tabular}

Notes:

a. Budget estimates are derived from the following sources: for VLSI Project, see Flamm. (Mismanoged Trade? op.cit); for SEMATECH, 1300I, and International SEMATECH, see SEMATECH (1997, op.cit) plus personal communication; for Selete, see Selete (1997, op. cit.); for ASET, see ASET (1997, op, cit) and personal communication.

b. 1996 budget includes 13001

c. 1997 budget includes 13001: 1998 includes International SEMATECH

the Japanese semiconductor firms played a guiding role in orchestrating the publicly funded ASET project. During Japan's "catch up" phase in the 1970s, MITI and NTT (then a state-owned telecommunications firm) provided much of the impetus for the creation of the VLSI Project and its parallel projects with suppliers. ${ }^{69}$ As Japan entered the 1980 s, however, the ability of the government 
TABLE 4. An Overview of Major and Recent Semiconductor Consortia in the United States and Japan (continued)

\begin{tabular}{|c|c|c|c|}
\hline Consortium & Member Firms & Suppliers & Primary Activities \\
\hline VLSI Project & $\begin{array}{l}\text { Five Japanese device makers: (NEC, } \\
\text { Fujitsu, Hitachi,Toshiba, Mitsubishi) }\end{array}$ & $\begin{array}{l}\text { Japanese } \\
\text { only }\end{array}$ & $\begin{array}{l}\text { R\&D on device, process, } \\
\text { materials, packaging, design, } \\
\text { and test technologies needed } \\
\text { for million-transistor chips }\end{array}$ \\
\hline SEMATECH & $\begin{array}{l}\text { Ten U.S.-based device makers (as of } \\
\text { 1997): (AMD, Digital, H-P, IBM Intel, } \\
\text { Lucent, Motorola, National, Rockwell,TI) }\end{array}$ & Mainly U.S. & $\begin{array}{l}\text { Current Technology Areas: } \\
\text { interconnect, front end processes, } \\
\text { assembly and packaging, design } \\
\text { systems, manufacturing methods. }\end{array}$ \\
\hline 13001 & $\begin{array}{l}\text { Original members: } 6 \text { SEMATECH } \\
\text { members + } 3 \text { Korean, I Taiwanese, } \\
3 \text { European firms; In 1998, includes all } \\
\text { members of International SEMATECH } \\
\text { (see Table 3) }\end{array}$ & Global & Standards, $300 \mathrm{~mm}$ tool evaluation \\
\hline $\begin{array}{l}\text { International } \\
\text { SEMATECH } \\
\text { (incl. I300I) }\end{array}$ & $\begin{array}{l}\text { All } 10 \text { SEMATECH members + } \\
\text { I Korean, I Taiwanese, } 3 \text { European } \\
\text { firms (see Table 3). }\end{array}$ & Global & $\begin{array}{l}\text { Standards, } 300 \mathrm{~mm} \text { tool } \\
\text { development, lithography, } \\
\text { environmental, health \& safety }\end{array}$ \\
\hline Selete & $\begin{array}{l}\text { Ten Japanese device makers: (NEC, } \\
\text { Hitachi,Toshiba, Mitsubishi, Fujitsu, } \\
\text { Matsushita, Sanyo, Oki, Sharp, Sony) }\end{array}$ & Global & $\begin{array}{l}300 \mathrm{~mm} \text { tool evaluation and } \\
\text { development, advanced } \\
\text { technology development } \\
\text { (lithography, computer-aided } \\
\text { design) }\end{array}$ \\
\hline ASET & $\begin{array}{l}16 \text { members of semiconductor proj- } \\
\text { ects: } 10 \text { Selete members + } 4 \text { Japanese } \\
\text { equipment firms (Advantest, JEOL Ltd, } \\
\text { SPC Electronics, Toshiba Machine Co.) } \\
+ \text { I Japanese government lab (NTT-AT) } \\
+ \text { I Japanese subsidiary of a U.S. firm } \\
\text { (Texas Instruments) }\end{array}$ & $\begin{array}{l}\text { Japanese } \\
\text { only }\end{array}$ & $\begin{array}{l}6 \text { semiconductor R\&D projects: } \\
3 \text { in lithography, I in mask fabri- } \\
\text { cation, I in diagnostics, I in } \\
\text { particle control and cleaning } \\
\text { (the only semiconductor project } \\
\text { including non-Japanese firm) }\end{array}$ \\
\hline
\end{tabular}

to implement an effective industrial policy in the electronics industry declined. The success of Japanese firms translated into larger corporate R\&D budgets and "increasingly confident Japanese firms cast off their dependence on MITI and refused to contribute funds to MITI consortia, ${ }^{\prime 70}$ During the $1980 \mathrm{~s}$, a second shift occurred in MITI-sponsored projects with high-technology firms: MITI redirected its joint projects with industry away from the "catch up" programs aimed at improving existing technologies developed in the United States and toward projects that would advance the technological frontier. ${ }^{71}$ The result was that MITI's two major RED efforts in the electronics and information technology sectors in the 1980s, the Supercomputer and Fifth Generation projects, focused 
on long-term R\&D, faced resistance by companies, were hamstrung by small budgets, and ultimately were not very successful. ${ }^{72}$

Within this context, the creation of Selete and ASET represents a new era of private-public collaboration in Japan, triggered by the first major challenge to the competitive performance of Japanese device makers since the 1970s. Rather than being coerced into collaboration, which was the case in the 1970s, leading Japanese semiconductor firms initiated the latest round of cooperation. Needless to say, in the absence of a competitive crisis in the Japanese semiconductor industry, it is unlikely that projects of this magnitude would have been launched.

\section{Conclusion}

Although the competitive performance of semiconductor firms in the global market is driven by a complex array of macroeconomic, technological, and institutional influences, ${ }^{73}$ the two newly formed semiconductor consortia examined here-the U.S.-based International 300mm Initiative and the Japanbased Selete consortium-are closely tied to the historic ebbs and flows in the relative performance of U.S. and Japanese firms. The formation of I300I coincided with a period of relative strength for U.S. semiconductor manufacturers and the domestic base of supplier firms. Perhaps as a result, I300I's members were reluctant to fund a major development project, settling for a less ambitious set of activities aimed at setting standards and demonstrating tool performance. However, the importance of I300I extends beyond its relatively narrow role in the $300 \mathrm{~mm}$ wafer conversion. I300I has already been an important experiment of international collaboration for its parent organization, SEMATECH-which, having shed its partnership with the U.S. government in 1996, created a new "International SEMATECH" in 1998.

By contrast, the Japan-based Selete consortium was established at a time when leading Japanese device makers were engaged in efforts to reactivate the Japanese industry in order to address their collective problems in worldwide semiconductor markets. In the 1990s, Japanese device makers lost market share to South Korean and Taiwanese firms in commodity product lines (e.g., DRAMs) that depend on manufacturing expertise and high-volume production. At the same time, Japanese firms have failed to make significant inroads in the lucrative, design-intensive end of the market (e.g., microprocessors) that remains dominated by U.S. firms. In response, Japanese semiconductor manufacturers launched an ambitious program aimed at improving next-generation manufacturing technologies based on the new wafer standard, and did so in conjunction with a large, publicly funded initiative, ASET.

From this perspective, the formation of Selete and ASET is analogous to the establishment of the U.S. SEMATECH consortium in the 1980s and Japan's VLSI Project in the preceding decade: periods of "collective crisis" have resulted in "collective action" that involves industry-wide coordination and, periodically, 
joint government-industry action in both nations' semiconductor industries. The critical nature of semiconductor components as inputs to the electronics, telecommunications, and computer industries means that governments are reluctant to ignore the erosion in the competitive performance of their domestic firms, while firms appear more likely to turn to governments during times of economic strain. At a minimum, this tendency suggests that a truly "borderless" world of global firms, one in which national governments exercise little or no influence, remains a distant mirage.

The lingering role of governments in shaping private sector collaboration is only one of several lessons from these consortia. A key difference between both I300I and Selete and the landmark semiconductor consortia of the past (i.e., SEMATECH and the VLSI Project) is that these new initiatives have been devised and funded by private firms; any government influence on the structure and design of these consortia was indirect. As such, these industry consortia yield important insights concerning the private incentives for collaboration among firms in this industry. The semiconductor industry appears to be unique in the extent to which leading manufacturers are now working together worldwide to establish uniform standards for manufacturing technologies. The complexity and costs of semiconductor manufacturing, combined with the short product life cycles and rapid pace of technological change in this industry, have triggered an unprecedented level of collaboration among device makers in guiding the industry's conversion to $300 \mathrm{~mm}$ wafers. ${ }^{74}$ Furthermore, without the direct involvement of governments in their collective activities, both of these consortia chose to include a broad base of suppliers from around the world in their vertical projects.

A more cautionary lesson from these privately held consortia is that even in the face of unprecedented cooperation, the transition to a new technology ( $300 \mathrm{~mm}$ wafers in this case) may be impeded by unforeseen events. The recent industry slowdown and the faster-than-expected improvements in $200 \mathrm{~mm}$ fabs have delayed the need to introduce $300 \mathrm{~mm}$ tools. As noted earlier, this situation illustrates an important risk associated with the collective priority-setting and technological forecasting of industry-wide consortia. By the summer of 1998 , what was once called "collaboration" was deemed a "crisis," as supplier firms found it difficult to support their investments in $300 \mathrm{~mm}$ tools when purchase dates slipped further into the future.

The projects at I300I and Selete are still underway. Whether these consortia will be remembered for ushering in a new era of international cooperation among semiconductor manufacturers and their suppliers, or for contributing to its demise, remains to be seen. 


\section{Notes}

1. N.S. Vonortas, "Research Joint Ventures in the U.S.," Research Policy, 26/4-5 (1997): 577-595. See also H.E. Aldrich and T. Sasaki, "R\&D Consortia in the U.S. and Japan," Research Policy, 24/2 (1995): 301-316.

2. R.M. Ham and D.C. Mowery, "Enduring Dilemmas in U.S. Technology Policy," California Management Review, $37 / 4$ (Summer 1995): 89-107. Although this article concentrates on publicly funded semiconductor consortia in the United States and Japan, a host of European-wide consortia were launched during the 1980s in the broad areas of information technologies. These include ESPRIT (European Strategic Program for R\&D in Information Technologies), Eureka (a large-scale initiative in electronic technologies), and JESSI (the Joint European Submicron Silicon Initiative). JESSI was undertaken within the Eureka framework to "strengthen the whole European electronics chain and also to secure its worldwide competitiveness in the future." N. Lucchini, "European Technology Policy and R\&D Consortia: The Case of Semiconductors," International Journal of Technology Management, 15/6 (1998): 542-555. See also T.C. Lawton, Technology and The New Diplomacy: The Creation and Control of EC Industrial Policy for Semiconductors (Aldershot, UK: Avebury Press, 1997).

3. Throughout this article, a research consortium is broadly defined as an agreement in which multiple firms agree to share the expenses and the benefits associated with a future R\&D activity. A consortium may include provisions for sharing the cost or effort of conducting R\&D, may or may not conduct research at a common facility, and may entail a complex array of licensing and intellectual property provisions for member versus nonmember firms. A consortium typically includes more members and pursues a broader agenda than a narrowly focused research joint venture.

4. The U.S. SEMATECH consortium, for example, was heralded as "a model for federal consortia funded to advance other critical technologies. Programs will be encouraged in the development of a new automobile, new construction technologies, intelligent control and sensor technologies, rapid prototyping, and environmentally conscious manufacturing." W. Clinton and A. Gore, "Technology for America's Economic Growth: A New Direction to Build Economic Strength," White House Press Office, February 22, 1993, cited in P. Grindley, D.C. Mowery, and B. Silverman, "SEMATECH and Collaborative Research: Lessons in the Design of High-Technology Consortia," Journal of Policy Analysis and Management, 13/4 (1994): 723-758, at p. 723.

5. J. Macher, D.C. Mowery, and D. Hodges, "Back to Dominance? U.S. Resurgence in the Global Semiconductor Industry," California Management Review, 41/1 (Fall 1998) [in this issue].

6. M. Fransman, The Market and Beyond: Cooperation and Competition in Information Technology Development in the Japanese System (Cambridge, UK: Cambridge University Press, 1990).

7. The direct effects of the VLSI Project on the competitive performance of Japanese device makers and equipment firms are far from clear. See, for example, R. Langlois and W.E. Steinmueller, "The Evolution of Competitive Advantage in the Global Semiconductor Industry: 1947-1996," in D.C. Mowery and R.R. Nelson, eds., The Sources of Industrial Leadership (New York, NY: Cambridge University Press, 1998).

8. Although this article focuses on the two leading consortia (I300I and Selete) involved in the $300 \mathrm{~mm}$ transition, there are several related European initiatives. For example, the Semiconductor Equipment Assessment (SEA) program under ESPRIT promotes European equipment suppliers, but some of the $300 \mathrm{~mm}$ equip- 
ment under that program will be evaluated by I300I and Selete. Europe is also developing some of its own $300 \mathrm{~mm}$ tools as part of the four-year, $\$ 2.5$ billion Microelectronics Development for European Applications (MEDEA) project, which is funded jointly by government and industry. J. Haystead, "Making the Right Moves," Electronic Business Today (February 1997), pp. 52-57; Semiconductor Equipment and Materials International (SEMI), "U.S. Semiconductor Manufacturing and the $300 \mathrm{~mm}$ Challenge," www.semi.org/Focused/public/wp/whitepaper.html, 1997.

9. In order to investigate the factors that underpin the formation of these consortia, we met with representatives from both $\mathrm{I} 300 \mathrm{I}$ and Selete and with other industry executives involved in this and prior wafer transitions. We conducted over 20 interviews with these individuals between June 1997 and August 1998.

10. J.H. Dunning, Globalization: The Challenge for National Economic Regimes [The Geary Lecture for 1993] (Dublin: Economic and Social Research Institute, 1994).

11. In 1996, for a group of leading U.S. producers with combined semiconductor sales of over $\$ 37$ billion, semiconductor-specific capital expenditures amounted to more than 25 percent of sales, while research and development expenditures were nearly 12 percent of sales. Based on data from Integrated Circuit Engineering Corporation (ICE), Profiles 1997 (Scottsdale, AZ: Integrated Circuit Engineering, Inc., 1997). Both figures outweigh the corresponding data for leaders in other industries such as chemicals, pharmaceuticals, aerospace, and autos (Calculated from 10-K reports for Dow Chemical, Merck \& Co., Boeing, and Ford Motor).

12. "Philips Executive Urges New Alliances between Chip and Equipment Companies," Semiconductor Business News Online, October 8, 1997.

13. M.M. Appleyard, N.W. Hatch, and D.C. Mowery, "Managing New Process Introduction in the Semiconductor Industry," in G. Dosi, R. Nelson, S. Winter, eds., Corporate Capabilities and Competitiveness (London: Pinter, forthcoming). See also E. Braun and S. MacDonald, Revolution in Miniature: The History and Impact of Semiconductor Electronics (Bath, UK: Pitman Press, 1982) for an excellent discussion of the historic reliance of semiconductor firms on manufacturing process technologies.

14. "Applying Pressure," Electronic Business (November 1997).

15. Semiconductor production involves the creation of multiple copies of an integrated circuit design on a round silicon wafer. In simple terms, larger wafersholding the number of wafers produced in a given facility constant-permit more chips to be manufactured. For example, the move from $100 \mathrm{~mm}$ to $150 \mathrm{~mm}$ wafers (a 1.5x increase in wafer diameter) doubled the number of chips per wafer, while the move from $200 \mathrm{~mm}$ to $300 \mathrm{~mm}$ wafers (again, a $1.5 \mathrm{x}$ increase in wafer diameter) yields approximately 2.6 times more identically sized chips per wafer. Plant throughput can also be improved by reducing the size of a given design (e.g., through a re-design of the device or through switching to a process using finer line widths), permitting more chips to fit on each processed wafer.

16. New chip designs are typically brought to market as rapidly as possible in order to earn the price premium associated with state-of-the-art products. Designs are then "shrunk" in later versions in order to economize on wafer space (reducing cost) and also to enhance the chip's speed and performance.

17. Integrated Circuit Engineering Corporation (ICE), Cost Effective Manufacturing, 19981999 (Scottsdale, AZ: Integrated Circuit Engineering, Inc., 1997).

18. Because individual equipment firms and device makers incur part of the costs of any given wafer conversion, precise estimates are difficult to obtain. Estimates of the total cost of putting $300 \mathrm{~mm}$ technology into practice have been as high as $\$ 30$ billion, of which $\$ 14$ billion would be spent for development by equipment suppliers and the rest by chip companies to implement the new systems. See, for example, Semiconductor Business News, "Move to 300-mm Slows to a Walk" 
(December 1997). As of mid-1998, equipment suppliers had already spent an estimated \$4 billion on 300mm development. "Summit Called to Help Avert 300mm Crisis," Semiconductor Business News, July 13, 1998.

19. SEMI, op. cit.

20. A former IBM engineer we interviewed used the term "fiasco" to describe IBM's experience in the transition to $200 \mathrm{~mm}$ wafers.

21. See, for example, "IBM Boosts Production of Memory Chips with Debut of 8-inch Wafer," PC Week, June 7, 1988; Haystead, op. cit.

22. A variety of standards-setting organizations have been involved in orchestrating dialogue among international device makers and between these manufacturers and the suppliers of semiconductor materials and equipment. Foremost among these are SEMI, an international organization for semiconductor equipment and materials suppliers, and J300, a volunteer industry roundtable in Japan that includes device, equipment, and materials companies. I300I has also taken an active role in standards development. For example, starting in July 1997, I300I and J300 published a series of "Global Joint Guidance" documents related to $300 \mathrm{~mm}$ equipment and factory automation. In contrast, during the previous transition to $200 \mathrm{~mm}$ wafers, the lack of industry standards resulted in a myriad of options for each piece of equipment: "200mm processing equipment has no standard equipment interface and there are multiple differences in loading height, depth, and direction by equipment manufacturer and equipment type." ICE, op. cit.

23. STMicroelectronics was known as SGS-Thomson until May 1998.

24. At the end of 1997, two of the Korean firms (Samsung Electronics and LG Semicon) terminated their membership, citing the effects of the Asian financial crisis. "Samsung Stays in Japan's 300mm Group After Leaving SEMATECH's," Electronic Buyers' News Daily Digest, February 4, 1998.

25. Samsung joined Selete's $300 \mathrm{~mm}$ program as a "client" in September 1997 and, by mid-1998, had placed several assignees at Selete. Samsung is not, however, a stockholder of the consortium and thereby has no formal role in setting or redirecting Selete's research activities. Interview with Dr. Hiroyoshi Komiya, Executive Vice President and COO of Selete, May 15, 1998. See also, "Samsung Stays in Japan's 300mm Group After Leaving SEMATECH's," Electronic Buyers' News Daily Digest, February 4, 1998.

26. T.F. Bresnahan and A. Chopra, "The Development of the Local Area Network Market as Determined by User Needs," Economics of Innovation and New Technology, 1/182 (1990): 97-110. Leading manufacturers in other capital-intensive industries have nonetheless played an important (but less coordinated) role in establishing standards for production equipment, especially in the automobile industry. For example, General Motors led the development of a computer-integrated manufacturing standard, the Manufacturing Automation Protocol (MAP), that obviated the need to write expensive, customized "bridge" software to coordinate a diverse array of automated machine tools based on separate, incompatible systems. Gabel details how buyers promulgated supplier standards in the auto industry's early years up to 1930. H.L. Gabel, Competitive Strategies for Product Standards: The Strategic Use of Compatibility Standards for Competitive Advantage (New York, NY: McGraw-Hill, 1991), Chapter 4. More recently, Detroit's Big Three established the United States Council of Automotive Research (USCAR) in the wake of the 1984 NCRA. USCAR is roughly comparable to SEMATECH, conducting a wide range of precompetitive activities in cooperation with various sets of vendors. It has not yet been revealed how USCAR will respond to its potential internationalization following the takeover of Chrysler by Germany's Daimler-Benz. 
27. Semiconductor producers originally developed their equipment internally. Independent equipment producers emerged in the United States in the 1970s and, soon thereafter, in Europe and Japan. W.J. Spencer and P. Grindley, "SEMATECH after Five Years: High-Technology Consortia and U.S. Competitiveness," California Management Review, 35/4 (Summer 1993): 9-32.

28. M.M. Appleyard, "The Strategic Development of Equipment: Buyer-Supplier CoDevelopment in the Semiconductor Industry," Darden Working Paper Series DSWP-98-05, Colgate Darden Graduate School of Business Administration, University of Virginia, 1998. In a more recent development, some large suppliers, such as U.S.-based Applied Materials, have integrated their product lines more fully and are performing some of the tests typically conducted by manufacturers. "Applied Opens Metrology Lab to Accelerate 300-mm Work," Semiconductor Business News Online, July 10, 1997.

29. Appleyard, op. cit. The device maker attributed the failure to a lack of involvement by the supplier early in the overall process development project of which the tool was one element.

30. A fundamental risk faced by the industry is whether the capital costs of nextgeneration fabs will undermine the profitability of the $300 \mathrm{~mm}$ transition. The goal set by device manufacturers is that $300 \mathrm{~mm}$ capital costs should not exceed $1.3 \mathrm{x}$ those for $200 \mathrm{~mm}$ fabs, but the cost of some pieces of equipment will most likely exceed this target. "SEMI's 300-mm Symposium: Tough Times Slow the Wafer Transition," Global 300mm Report (July 1998).

31. Some administrative and procedural safeguards were put in place to separate the activities of 13001 and SEMATECH, in part because of the higher dues paid by SEMATECH members (four of which were not part of I300I until 1998) and, perhaps more importantly, because of lingering political concerns over the leakage to foreign firms of research that was previously supported by U.S. government funds (also discussed below). See, "SEMATECH Vowing to Protect Taxpayer-Funded R\&D Data," New Technology Business Week, February 9, 1998.

32. SEMATECH, 1997 Annual Report: 10 Years of Shared Experience, (Austin, TX: SEMATECH, 1997).

33. The cost-of-ownership model estimates the lifetime cost-including purchase, support, service, and maintenance costs-for individual pieces of equipment and has proved to be very beneficial in guiding tool development. For example, Intel estimates that use of the $\mathrm{COO}$ model has reduced by more than 50 percent the operating costs associated with a Lam Research etching tool. Grindley et al., op. cit.

34. Grindley et al., op. cit. While SEMATECH spent roughly 20 percent of its 1988 budget on supplier contracts, over 60 percent of it \$200 million 1991 budget was allocated to these external activities. U.S. General Accounting Office, SEMATECH's Technological Progress and Proposed ReD Program, GAO/RCED-92-233BR (Washington, D.C.: Government Printing Office, 1992).

35. According to representatives from I300I, half of the demonstrations conducted by May 1998 had taken place off-site at supplier firms. I300I evaluates some tools, especially ones used to support the overall demonstration process, in the clean room it leases from SEMATECH.

36. As discussed below, however, the next phase of I300I's 300mm-related activities may involve joint projects with suppliers on selected pieces of equipment. Interview with Frank Robertson, General Manager, I300I, May 1998.

37. SEMATECH, SEMATECH Technology Patents, Technology Transfer Report \#9303151588B-XFR (Austin, TX: SEMATECH, Inc., 1995); updates available at http://www.sematech.org/public/general/issued.htm. 
38. K. Flamm, Mismanaged Trade? Strategic Policy and the Semiconductor Industry (Washington, D.C.: Brookings Institution, 1996). As discussed below, this industry "think tank" proposed and funded several initiatives, including the Selete consortium, several semiconductor projects funded by MITI (discussed in the section titled "Global Firms, National Governments" in this article), and the Semiconductor Technology Academic Research Center (STARC), a program modeled explicitly after the U.S. Semiconductor Research Center (SRC) that funds university research. Interview with Taro Okabe, Executive Researcher and Acting Executive Director of SIRIJ, July 1998; see also Flamm, op. cit.

39. Since 1995, SIRIJ has added three new members, of which one (TI Japan) is a Japanese subsidiary of a U.S. firm and another (Nippon Motorola) is a joint venture between a Japanese and a U.S. firm. Flamm, op. cit. These new SIRIJ members have not joined Selete.

40. In a July 15, 1995, letter to SEMATECH, the director of SIRIJ cited three reasons for the decision by Japanese device makers to decline the invitation to join I300I: the distance between Japan and Austin, Texas (where the I300I consortium would be located), language barriers, and differences between leading U.S. and Japanese device makers in their "philosophies" of manufacturing. The letter stated further that "a few leading Japanese companies still believe that they have to have unique production equipments [sic] in order to differentiate their products from others. I think such philosophy is not popular in the U.S." The Japanese executives we interviewed also asserted that the global semiconductor equipment sector benefits from having two consortia instead of one. In theory, the existence of two separate consortia working on the $300 \mathrm{~mm}$ transition may avoid "lock-in" to sub-optimal equipment specifications. See W.B. Arthur, "Competing Technologies, Increasing Returns, and Lock-In by Historical Events," Economic Journal, 99 (1989): 116-131; and P.A. David, "Clio and the Economics of QWERTY," American Economic Review, 75 (1985): 332-337 on how the early, widespread adoption of one standard may lock-out emerging but superior alternatives.

41. One of the largest expenses in the transition effort is the purchase of the $300 \mathrm{~mm}$ wafers used for testing. A reliability test can use 1,000 or more wafers, which cost about \$1,000 apiece. I300I pays 20 percent of the cost of wafers used for testing with the suppliers covering the rest. In contrast, Selete purchases all of its test wafers. Selete, "Status of 300mm Program at Selete," SEMICON West ' 97 presentation, July 16, 1997.

42. As discussed below, Selete's clean room not only houses the consortium's 300mmrelated activities, but also supports "advanced technology research" programs in specific equipment areas, such as next-generation optical lithography and electron-beam direct writing technologies, which are supported by additional dues from member firms. Selete, op. cit. For example, Selete's first advanced technology research program-budgeted at $\$ 8$ million through the year 2000-was a computer-aided design project that simulated devices and processes. Selete's projects in advanced lithography and e-beam direct writing technologies are affiliated with government-funded projects in a separate initiative (discussed below). See, "Semiconductor Leading Edge Technologies, Inc. (Selete) Starts New Research on Future Technologies," Selete Press Release, July 10, 1997.

43. An executive we interviewed in 1997 from a major U.S. equipment firm expressed concern that participation in Selete would give the firm's Japanese competitors access to their proprietary technologies. Because of these concerns, the firm postponed shipment of its most critical tool to Selete until additional safeguards were put in place. [The representative from the equipment firm preferred to remain anonymous.] According to Hiroyoshi Komiya of Selete, however, Selete has taken considerable strides to ensure the confidentiality of tool-related 
information; although suppliers had initial questions about the security of proprietary information at Selete, Dr. Komiya was unaware of any reluctance among suppliers to place tools at the common facility. Written comments provided by Hiroyoshi Komiya, Executive Vice President and COO of Selete, September 1998.

44. Interview with Hiroyoshi Komiya, Executive Vice President and COO of Selete, May 1998.

45. An engineer interviewed in this study stated that tool "tweaks" (i.e., minor changes) constitute some of the most valuable intellectual property in the semiconductor equipment industry.

46. Written comments provided by Hiroyoshi Komiya, Executive Vice President and COO of Selete, September 1998.

47. The potential cost savings from cooperation to avoid redundancy are considerable. For example, each consortium puts semiconductor production equipment through "marathon" and "ironman" tests, which cost around \$1 million each, to evaluate the stability of the equipment using different manufacturing processes and to assess the reliability of the equipment. A.S. Longo, "The Evaluation and Implementation of Process Technologies in Semiconductor Manufacturing," unpublished master's thesis, MIT Sloan School of Management, 1995, at p. 1. Each group, however, conducts these tests somewhat differently and cooperation has proved to be more elusive in this area than in standards-setting activities. By the end of 1997, following two years of discussion, some agreement had been reached on a joint "ironman"-style test, one of which was conducted in early 1998. Interview with Frank Robertson, General Manager, I300I, May 1998. The consortia have also worked together on developing "unified metrics" for equipment, which would establish consistent targets for suppliers. By December 1997, they had converged on metrics for 15 tools capable of 250 nanometer $(\mathrm{nm})$ processing and, by June 1998, metrics had been agreed upon for an additional 17 tools capable of processing at the more advanced 180nm technology. I300I presentation at SEMICON West, July 1998.

48. In 1997, I300I started demonstration projects of tools from a number of different vendors worldwide, including Applied Materials (U.S.), JEOL (Japan), Leica (Europe), TEL (Japan), Tencor (U.S.) and Verteq (U.S. ); ICE, op. cit. at p. 7-10.

49. Interviews with Hiroyoshi Komiya, Executive Vice President and COO of Selete, and Frank Robertson, General Manager, I300I, May 1998.

50. Texas Instruments presentation at SEMI 3rd Annual 300mm Symposium, June 16, 1998.

51. "SEMI Regional Meeting Focuses on 300-mm Transition Status," Global 300mm Report, March 1998. Non-compliance is a risk in any standards effort. For example, the Open Systems movement in midrange computers was splintered by the 1988 creation of the Open Software Foundation in response to AT\&T's perceived dominance of the UNIX standard. Gabel, op. cit., Chapter 5.

52. This is a common problem in electronics and complicates the timing of new product introductions. For example, producers of long-established cathode ray tubes have continued to make improvements and cost reductions, providing a moving target for competing technologies such as liquid crystal and plasma displays. See, for example, B. Bowonder, S.L. Sarnot, M.S. Rao, and T. Miyake, "Competition in the Global Electronics Industry: Strategies of Major Players," International Journal of Technology Management, 12/586, Special Issue (1996), pp. 551-576.

53. "SEMI Regional Meeting Focuses on 300-mm Transition Status," Global 300mm Report, March 1998. The one 1998 pilot line predicted in the March forecast-a Siemens-Motorola joint venture in Dresden, Germany-has been delayed due to lack of a complete tool set. "Siemens Hedging on Whether It Will Meet 300-mm Schedule," Semiconductor Business News (August, 1998). 
54. "Applied Materials Profit Drops, Forecasting an Industry Slump," Wall Street Journal Interactive Edition, July 13, 1998.

55. For example, some industry representatives have called into question the need for $300 \mathrm{~mm}$ wafers, suggesting the need to move to $400 \mathrm{~mm}$ wafers instead. "Could 400-mm Wafers Be Coming Sooner?" Semiconductor Business News, June 15, 1998.

56. Dunning, op. cit.

57. Restrictions on foreign participation in SEMATECH were originally put in place because of the U.S. government's contributions and the objective of the consortium to bolster the domestic semiconductor industry. Grindley et al., op. cit.

58. J.B. Horrigan, "Cooperation Among Competitors in Research Consortia: The Evolution of MCC and SEMATECH," unpublished doctoral dissertation, University of Texas at Austin, 1996.

59. Ham and Mowery, op. cit.

60. International SEMATECH is a wholly owned subsidiary of SEMATECH, although each company has its own advisory board structure. Both International SEMATECH and SEMATECH are funded by dues from member companies, with funding divided about evenly between the two. Overall member dues to SEMATECH did not change as a result of the expansion; some ongoing SEMATECH projects were simply transferred to the international subsidiary. See Table 4 for information on the projects conducted by the two organizations.

61. These projects may be absorbed into other divisions of International SEMATECH at that time.

62. M. Crawford, "SEMATECH Vowing to Protect Taxpayer-Funded RED Data," New Technology Week, February 9, 1998.

63. A SEMATECH executive we interviewed speculated that, had the Japanese joined I300I, Congress might have derailed the entire initiative. Debate over granting membership to non-U.S. firms rang through the halls of the U.S. RED establishment in the 1980s, and was revived quite recently by the controversial EUV consortium, an industry group led by Intel that wanted to include Nikon, a Japanese supplier of nearly half the world's semiconductor lithography equipment, in a collaborative RED project with U.S. government engineers. In the end, Congress barred the direct participation of non-U.S. firms (including Nikon) in the project, but allowed the results of the project to be licensed to equipment suppliers worldwide. See, "Global Chip Effort Set; International SEMATECH: Consortium May Be Hindered by Lack of Japanese Firms," Mercury Center (San Jose Mercury News Online), February 3, 1998; "U.S.-Funded Technology Stays Here for Now," U.S. News and World Report, May 18, 1998, p. 5.

64. Flamm, op. cit.

65. Interview with Taro Okabe, Acting Executive Director, Semiconductor Industry Research Institute Japan (SIRIJ), July 1998. The decision by MITI to fund only the second set of longer-term projects may stem from a desire by the Japanese government to stay within the boundaries of the new GATT rules that define "nonactionable" R\&D subsidies of national governments (Flamm, op. cit.). For an analysis of the GATT rules, see H. Furuya, "Comparative Technology Policy for the Semiconductor Industry in Japan and the United States," unpublished master's thesis, Stanford Program in International Legal Studies, Stanford Law School, 1998; U.S. General Accounting Office, General Agreement on Tariffs and Trade: Uruguay Round Final Act Should Produce Overall U.S. Economic Gains, Volume 2, GAO/GGD-94-83B (Washington, D.C.: Government Printing Office, 1994).

66. ASET's funding during the current financial crisis sheds new light on the political rationale for industrial policy in contemporary Japan. In 1997, due to general budget cuts, ASET's funding was only $\$ 20$ million. But in 1998, the funding was raised to more than $\$ 70$ million as part of a fiscal stimulus package. 
67. In addition to the five semiconductor projects proposed by the members of Selete, MITI agreed to fund an additional semiconductor project (on particle contamination) that includes the Japan-based subsidiary of a U.S. firm, Texas Instruments. MITI also added projects to ASET in liquid crystal displays and magnetic storage devices, which include both Japanese firms and the Japanese-based subsidiaries of 3 foreign firms. See ASET, Present Activities and Future Vision of the Association of Super-Advanced Electronics Technologies (Tokyo: Electronic Industries Association of Japan, 1997). Only Japanese device manufacturers and suppliers, however, are involved in the five central semiconductor projects of ASET (see Table 4).

68. The second ASET project housed at Selete was terminated at the end of fiscal year 1997. Written comments by Hiroyoshi Komiya, Executive Vice President and COO, Selete, September 1998. The fact that ASET's ArF lithography project was transferred to Selete within such a relatively short timeframe appears to support Flamm's assessment that ASET is "best understood as advanced development effort than basic research... [despite being] characterized by its promoters as 'fundamental' or 'basic' technologies for future generation manufacturing." K. Flamm, "Japan's New Semiconductor Technology Programs," ATIP Report \#96.091, Asian Technology Information Program, www.atip.org, 1996, at p. 8.

69. According to Fransman, the Japanese device makers only accepted the joint laboratory portion of MITI's proposed organization because they "were forced to do so" in order to get the private research subsidies from MITI that they really wanted. Fransman, op. cit., p. 63.

70. S. Callon, Divided Sun: MITI and the Breakdown of Japanese High-Tech Industrial Policy, 1975-93 (Stanford, CA: Stanford University Press, 1995), at p. 13.

71. M. Anchordoguy, "Japan at a Technological Crossroads: Does Change Support Convergence Theory?" Journal of Japanese Studies, $23 / 2$ (1997): 363-397; Callon, op. cit.

72. Callon, op. cit.

73. See Macher et al., op. cit., for a thorough discussion of these issues.

74. Industry participants on both sides of the Pacific have considered deriving a joint technology roadmap for the direction of semiconductor technologies well into the future, although the benefits of these efforts are still being debated. "Work Starts on Global IC Roadmap," Semiconductor Business News, July 15, 1998. 
Copyright of California Management Review is the property of California Management Review and its content may not be copied or emailed to multiple sites or posted to a listserv without the copyright holder's express written permission. However, users may print, download, or email articles for individual use. 